\title{
Dendroflora of the Nataliivskyi Park (Kharkiv region, Ukraine): taxonomic diversity and monitoring of plantations
}

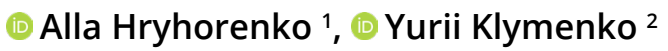 \\ 1 State Ecological Academy of Post-Graduate Education and Management, V. Lypkivskogo str. 35, 03035 Kyiv, Ukraine; \\ alla_gr@ukr.net \\ ${ }^{2}$ M.M. Gryshko National Botanical Garden, National Academy of Sciences of Ukraine, Tymiryazevska str. 1, 01014 Kyiv, Ukraine; \\ klimenco109@ukr.net
}

Received: 23.10.2020 | Accepted: 07.02.2021 | Published online: 23.03.2021

\begin{abstract}
To develop measures for the restoration of historic plantations and landscapes of the Nataliivskyi Park (Kharkiv region, Ukraine), the investigations of taxonomic composition and distribution of woody plant taxa, as well as structure of different landscape areas, were carried out in 2018-2019. The recent studies were realized according to the same protocol applied in 1997 by Y. Klymenko, and taking into account previously published data.

In 1939, the dendroflora of the Nataliivskyi Park comprised about 100 taxa. Later, the number of taxa significantly decreased, and in 1950 the park's dendroflora comprised only about 40 taxa. In 1997 there were 74 taxa reported. Since 1997, the taxonomic composition of the park's dendroflora has been enriched by ten taxa and is currently represented by 84 taxa. Simultaneously, the number of valuable plants in the plantations decreased (only one or two plants represent some such taxa). Due to a bark beetle attack on drought-weakened trees of Picea abies and P. pungens, most of them withered. The area of allotments with Pinus sylvestris and Quercus robur remained almost the same, which indicates their stability. The area of allotments with the domination of such naturalized introducers as Acer negundo and Robinia pseudoacacia and the area of allotments with the domination of neither taxa have increased. In the landscapes, the redistribution of the types of areas appeared. The forest type of landscape became predominant, while the meadow type of landscape has almost disappeared.

Hence, to restore historical plantings and landscapes, it is necessary to re-cultivate taxa represented here during the park's heyday and remove invasive tree species. Although cuttings in protected areas are currently prohibited, our investigations showed that they might help preserve such valuable territories as Nataliivskyi Park.
\end{abstract}

Keywords: Nataliivskyi Park, monitoring, taxonomic structure, landscapes planning, wood plantings

Authors' contributions: Alla Hryhorenko took part in park surveys in 2018-2019, composed species lists, worked on data discussion and conclusions forming. Yurii Klymenko conducted a 1997 investigation, took part in 2018-2019 investigations, created illustrations, worked on data discussion and conclusions forming.

Funding: The work has been conducted within the following research programs: 1997 - research program of the Dendrology and Park Science Department of the M.M. Gryshko National Botanical Garden "Scientific principles of studying, preserving and forming of cultural dendroflora gene pool in collection and park plantations of Polissya and Forest-Steppe of Ukraine" (state registration number 01954002739); 2018-2019 - research program of the Dendrology Department of the M.M. Gryshko National Botanical Garden "Ecological and biological principles of enrichment, recovery, and preservation of the collection, urban and park man-made phytocoenoses in Ukraine under conditions of climatic and anthropogenic changes" (state registration number 0115U000708).

Competing Interests: The authors declare no conflict of interest. 


\section{Introduction}

The monitoring of conditions of botanical gardens and parks has great importance for their preservation and restoration. Every activity conducted in a park should follow conclusions and recommendations of monitoring reports. Monitoring also allows revealing tendencies that can be predicted for other similar areas. Methodological issues of conservation and restoration of old parks are discussed by many scientists (Bondar et al., 1974; Agaltsova, 1980; Ilinskaya, 1984; Uspenskaya et al., 1991; Sikora, 2016).

The Nataliivskyi Park was founded in 1884 by Ivan Kharytonenko in Volodymyrivka village of Krasnokutsk district of Kharkiv region, Ukraine. Only in certain places of the primary park area, old trees of Quercus robur L. grew, while most of the territory consisted of bare sands. On the sands, Pinus sylvestris L. plants were planted. As a result, the pine and oak forests are attached to the contemporary park area. Later, lawns and flowerbeds were created near the buildings, and exotic plants were planted closer to the river Merchyk (Klymenko \& Kuznetsov, 2015). Hence, the elevation in the recent park area varies from 113 to $154 \mathrm{~m}$ a.s.l.

The Nataliivskyi Park was examined by one of us in 1997 (Y. Klymenko, the results were not published), and in 2018-2019 it was examined for the second time by both of us using the same protocols. During this time, there was a lack of financial support for this park. Any (including sanitary) felling was prohibited. Moreover, tangible climate changes, including extensive droughts, occurred.

Therefore, our recent examination was important and should elucidate the influence of mentioned factors on the taxonomic composition and vegetation structure of the Nataliivskyi Park.

\section{Material and methods}

The total area of Nataliivskyi Park covers 48 ha. However, Mayak \& Cherkasova (1989), as well as the current landowner (Regional Tuberculosis Sanatorium "Volodymyrskyi"), ascribe only 37.8 ha to the park territory. Our surveys were realized by the route method in 2018-2019, taking into account the last indicated area.
The park territory has been subdivided into sections according to prevailing taxa and vegetation types. Sections representing the species with less than five plants per each (i.e., sections with no prevailing species) were marked with a special sign. Park landscapes were classified according to Rubtsov (1956, 1979), who distinguished six their main types: sylvatic, park, meadow, garden, regular, and alpine. Basing on this classification and topographical plan of the park received from the Mapgeofund of Ukraine, the schematic plan was drawn out, and the area of each landscape type was calculated in ArcView GIS 3.2a environment.

The plant names are provided according to Plants of the World Online (2021).

\section{Results and discussion}

The schematic plan of plantings of the Nataliivskyi Park in 1997 is represented in Fig. 1, and the respective plan for 2019 - in Fig. 2. In 22 years, some buildings, including historical ones, were destroyed. Some routes have disappeared, and some new were created. In general, the area under paths increased, while the area covered by buildings decreased. The area under plantings also slightly decreased (from 34.65 ha in 1997 to 34.55 ha in 2019).

In 1939, in the Nataliivskyi Park, trees and shrubs of around 100 taxa grew (Lypa et al., 1952). Later, the number of taxa significantly decreased, and in 1950 the park's dendroflora comprised only about 40 taxa (Lypa, 1960).

Kurdyuk (1966), whose research is precious since it reflects the initial structure of the park, reported the big (over 60 trees) groves composed by Picea abies (L.) H. Karst. and P. pungens Engelm. 'Glauca'. Smaller groves were composed by Pinus rigida Mill. (14 trees), Abies concolor (Gordon \& Glend.) Lindl. ex Hildebr. (six trees), Pinus pallasiana D. Don and P. strobus L. (about ten trees of each species). The author also mentioned two plants of Picea pungens 'Argentea', three plants of P. pungens 'Kosteriana', and several plants of P. glauca (Moench) Voss (currently recognized as P. laxa (Münchh.) Sarg.; including two cultivars 'Compressa' and 'Coerulea'). There also grew individual trees of Abies sibirica Ledeb., Juniperus virginiana L., and Thuja L. 


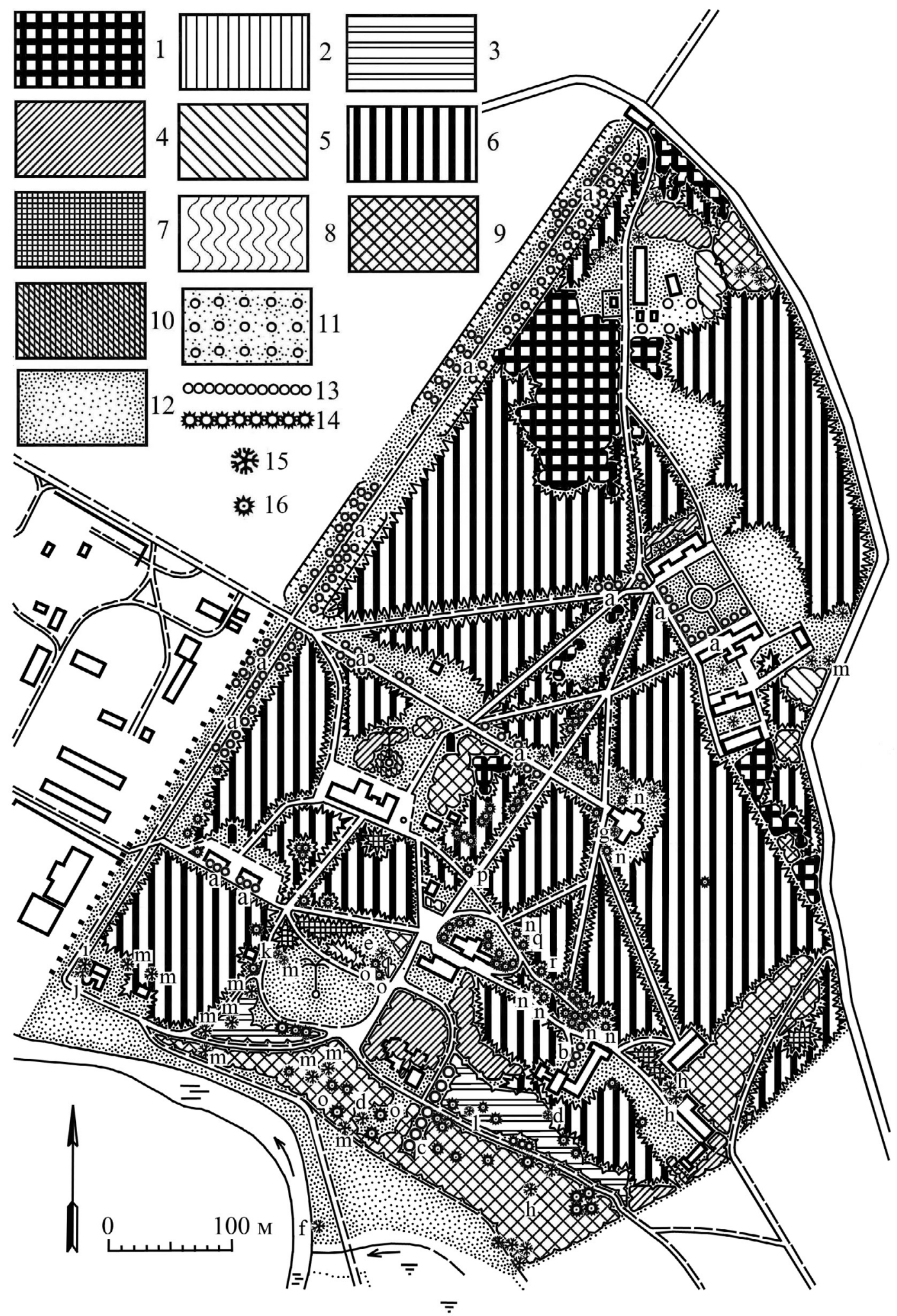

Figure 1. The schematic plan of plantings at the Nataliivskyi Park in 1997: 1 - Quercus robur; 2 - Tilia cordata; 3 - Ulmus laevis; 4 - Acer negundo; 5 - Robinia pseudoacacia; 6 - Pinus sylvestris; 7 - Picea abies; 8 - P. pungens; 9 - sections with no prevailing taxa; 10 - Sorbaria sorbifolia; 11 - orchard; 12 - lawns, meadows; 13 - rows of deciduous trees (a - Aesculus hippocastanum, b - Acer pseudoplatanus, c - Tilia cordata); 14 - the row of Picea abies; 15 - solitary deciduous trees (no letter mark - Quercus robur, d - Acer platanoides 'Cuculatum', e - A. platanoides 'Schwedleri', f - Alnus glutinosa, g - Betula pendula 'Yungii', h - Populus alba, i - P. nigra, j - Salix alba, $\mathbf{k}$ - Tilia tomentosa, I - Tilia americana, $\mathbf{m}$ - Ulmus laevis); 16 - solitary coniferous trees (no letter mark - Picea abies, $\mathbf{n}$ - P. pungens, $\mathbf{o}$ - Pinus nigra, $\mathbf{p}$ - P. strobus, $\mathbf{q}$ - Abies concolor, $\mathbf{r}$ - Pseudotsuga menziesii). 


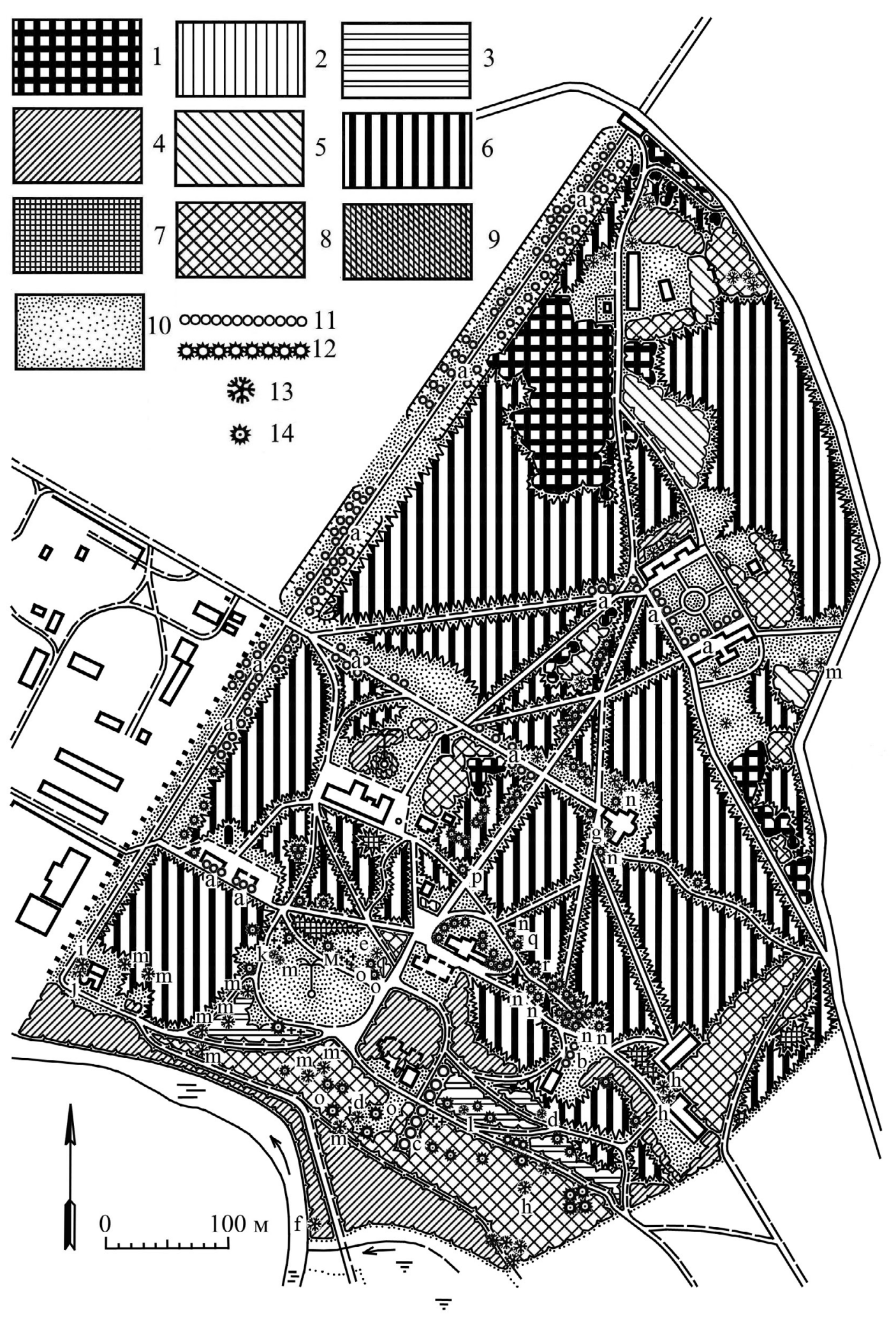

Figure 2. The schematic plan of plantings at the Nataliivskyi Park in 2019: 1 - Quercus robur; 2 - Tilia cordata; 3 - Ulmus laevis; 4 - Acer negundo; 5 - Robinia pseudoacacia; $\mathbf{6}$ - Pinus sylvestris; 7 - Picea abies; 8 - sections with no prevailing taxa; 9 - Sorbaria sorbifolia; 10 - lawns, meadows; 11 - rows of deciduous trees (a - Aesculus hippocastanum, $\mathbf{b}$ - Acer pseudoplatanus, c - Tilia cordata); 12 - the row of Picea abies; 13 - solitary deciduous trees (no letter mark - Quercus robur, $\mathbf{d}$ - Acer platanoides 'Cuculatum', e - A. platanoides 'Schwedleri', $\mathbf{f}$ - Alnus glutinosa, $\mathbf{g}$ - Betula pendula 'Yungii', h - Populus alba, i - P. nigra, j- Salix alba, k - Tilia cordata, I - T. americana, m - Ulmus laevis); 14 - solitary coniferous trees (no letter mark - Picea abies, $\mathbf{n}$ - P. pungens, o - Pinus nigra, $\mathbf{p}-$ P. strobus, $\mathbf{q}$ - Abies concolor, $\mathbf{r}$ - Pseudotsuga menziesii). 
Among angiosperms, there grew over 50 trees of Tilia platyphyllos Scop. (Kurdyuk, 1966). For certain alleys and groves, Kurdyuk reported the presence of $\mathrm{T}$. tomentosa Moench, T. dasystyla subsp. caucasica (V. Engl.) Pigott, T. xeuchlora K. Koch, and multiple trees of T. americana L. (including one tree of T. americana f. macrophylla (Fischer) V. Engler). Besides this, Kurdyuk also mentioned Aesculus pavia L., Quercus rubra L., Acer platanoides L. (including cultivars 'Schwedleri' and 'Cucullatum'), Betula pendula Roth 'Youngii'. Seven trees of Acer saccharinum L. (including two trees of cultivar 'Laciniatum' damaged by mistletoes) and 50 trees of Aesculus hippocastanum L. (damaged by polypore) were mentioned too.

There grew not many shrubs (represented mainly by Sambucus racemosa L., Philadelphus coronarius L., P. inodorus L., Syringa vulgaris L.), and all of them were distributed sporadically (Kurdyuk, 1966).

Later, the list of 22 taxa introduced in the park was published (Kokhno et al., 1975). The report of the examination of parks and arboretums of Kharkiv region (upublished, signed by Prylutska in 1976 and stored in Valkivskyi Local History Museum funds) listed 35 taxa of trees and shrubs (including 13 taxa of conifers).

According to Zharikov (1986), the following trees grew in the Nataliivskyi Park: Quercus robur, Q. palustris Münchh., Q. rubra, Fraxinus sp., Tilia cordata Mill., T. americana, Populus $\times$ canadensis Moench, Pinus sylvestris, Picea laxa, Abies balsamea (L.) Mill., Tsuga canadensis (L.) Carriere, Larix decidua Mill. and other.

Finally, Marchuk (2006) inventoried the park dendroflora and reported 69 species and four cultivars. Comparing our recent data with Marchuk's report, we found minor changes in the composition of plantings concerned only the species represented by a small number of individuals.

In 1997 there were 74 taxa reported, while in 2018-2019, we found 84 taxa (including 53 taxa of trees, 26 taxa of shrubs, three taxa of subshrubs, and two taxa of lianas) representing the park's dendroflora. The number of taxa has increased due to the recent plantings of ornamental and fruit plants near the building of Slobozhansky National Nature Park, which is located on the territory of the Nataliivskyi
Park, and penetration of some new species (e.g., Amorpha fruticosa L., Chaenomeles japonica (Thunb.) Lindl. ex Spach, Forsythia suspensa (Thunb.) Vahl, Prunus cerasus L., Rhus typhina L., Ribes uva-crispa L., Rosa rugosa Thunb., Rubus idaeus L., Spiraea salicifolia L., and S. × vanhouttei (Briot) Carrière). Besides this, such cultivars as Picea pungens 'Glauca', Juniperus communis L. 'Hibernica', Acer platanoides 'Cucullatum', A. platanoides 'Schwedleri', A. pseudoplatanus L. 'Purpureum', and Betula pendula 'Youngii' were detected.

Some taxa in the Nataliivskyi Park are represented by only a few plants. For example, Betula pendula 'Youngii' is represented by a single old tree, and Acer platanoides 'Cuculatum' - by only two trees. Many trees of Picea abies and P. pungens 'Glauca' were damaged by droughts in 2013, attacked by European spruce bark beetle, and, as a result, died. Most of those dead plants kept standing in their places due to felling prohibition. Today, only solitary trees of $P$. pungens 'Glauca' survived in the park. Hence, without restorative plantings, taxonomic diversity and projective cover of certain taxa in the park decrease (Table 1).

Today, the dominating species in the Nataliivskyi Park is Pinus sylvestris covering over $50 \%$ of the park's green area. The covering area of P. sylvestris decreased only slightly since 1997 due to the construction of unauthorized roads in the park and its consequent fragmentation. The area of lawns and meadows has significantly decreased. Various self-seeding plants (e.g., Robinia pseudoacacia L. and Acer negundo L.) occupied many open spaces.

Sections without prevailing taxa mainly appeared in the places where edificators fall out of dominance. Since 1997, the area of such sections has increased. In the northern part of the park, one of such sections consists of Acer platanoides, A. negundo, Populus tremula L., and Ulmus laevis Pall. In the central part of the park, such a section includes Catalpa speciosa Teas, Populus $\times$ canadensis, Pinus sylvestris, and other taxa. In the southern part of the park, there were small clumps and solitary trees of Tilia cordata, Aesculus hippocastanum, Picea abies, and Pinus nigra J.F. Arnold. Now the space between these trees is filled with Ulmus laevis, Acer platanoides, A. negundo, and other woody plants. In the south-eastern part 
Table 1. The dynamics of landscapes and selected taxa distribution in the Nataliivskyi Park.

\begin{tabular}{lllll}
\hline \multirow{2}{*}{ Sections } & \multicolumn{3}{c}{1997} & 2019 \\
\cline { 2 - 5 } & Area, ha & Area, \% & Area, ha & Area, \% \\
\hline Pinus sylvestris & 18.10 & 52.3 & 17.80 & 51.5 \\
Lawns, meadows & 6.85 & 19.8 & 4.85 & 14.0 \\
Sections with no prevailing taxa & 3.20 & 9.3 & 3.65 & 10.6 \\
Acer negundo & 1.15 & 3.3 & 2.75 & 8.0 \\
Quercus robur & 1.90 & 5.5 & 1.88 & 5.5 \\
Row of Aesculus hippocastanum & 1.45 & 4.2 & 1.45 & 4.2 \\
Ulmus laevis & 0.80 & 2.3 & 0.77 & 2.2 \\
Robinia pseudoacacia & 0.20 & 0.6 & 0.70 & 2.0 \\
Picea abies & 0.60 & 1.7 & 0.50 & 1.5 \\
Row of Tilia cordata & 0.10 & 0.3 & 0.10 & 0.3 \\
Tilia cordata & 0.04 & 0.1 & 0.04 & 0.1 \\
Sorbaria sorbifolia & 0.04 & 0.1 & 0.04 & 0.1 \\
Row of Acer pseudoplatanus & 0.01 & $<0.1$ & 0.01 & $<0.1$ \\
Row of Picea abies & 0.01 & $<0.1$ & 0.01 & $<0.1$ \\
Orchard & 0.15 & 0.4 & 0.00 & 0.0 \\
Picea pungens & 0.05 & 0.1 & 0.00 & 0.0 \\
\hline Total & 34.65 & 100.0 & 34.55 & 100.0 \\
\hline
\end{tabular}

of the park, there is a section that combines Ulmus laevis, Acer platanoides, A. negundo, Aesculus hippocastanum, Betula pendula, and solitary trees of Pinus sylvestris. Similarly, an orchard in the northern part of the park was overgrown by Ulmus laevis and Robinia pseudoacacia. In general, such species as Ulmus laevis, Robinia pseudoacacia, and Acer negundo actively occupy different areas of the park.

Historical plantings of Quercus robur are extremely valuable; their condition in the park is good. Only in certain oaks, there are tree hollows, there is no significant amount of dry branches in crowns, trees' affection by illness or pests, and there is no trees' dieback. Old trees of Pinus sylvestris, P. nigra, P. strobus, P. abies, Abies concolor, Ulmus laevis, Betula pendula 'Youngii', Pyrus communis L., and Robinia pseudoacacia preserved in the park too. The plot with Picea pungens 'Glauca' was entirely destroyed by disease and drought, but some old solitary trees of this cultivar preserved in other plots. From opposite, old plantings of Aesculus hippocastanum are currently dying, probably due to low fertility of the sandy soil and lack of moisture (this species is mesophyte requiring other soil conditions) and damage by the leaf-mining moth.

The sylvatic landscape was the primary type in the Nataliivskyi Park back in 1997 (Fig. 3). Inside forests, slight inclusions of the park and regular landscape types were present. True meadows could be found only along the river Merchyk, where the locals regularly mowed the grasses together with young seedlings of the trees. We also attributed to the meadow landscape a large glade (Fig. 3, a). The parterre that used to be in front of the palace disappeared. Only parterre area and alley plantings remained near the park's technical buildings (Fig. 4).

Since 1997, the total area of sylvatic landscape type had significantly increased (Table 2). The park type of landscapes decreased in certain places but appeared on some formerly open areas. The regular type of landscape is revealed unchanged, but the condition of alleys is imperfect. The parterre area is also overgrowing with self-seeded trees, changing from the regular into the park landscape type. Without mowing, meadows 


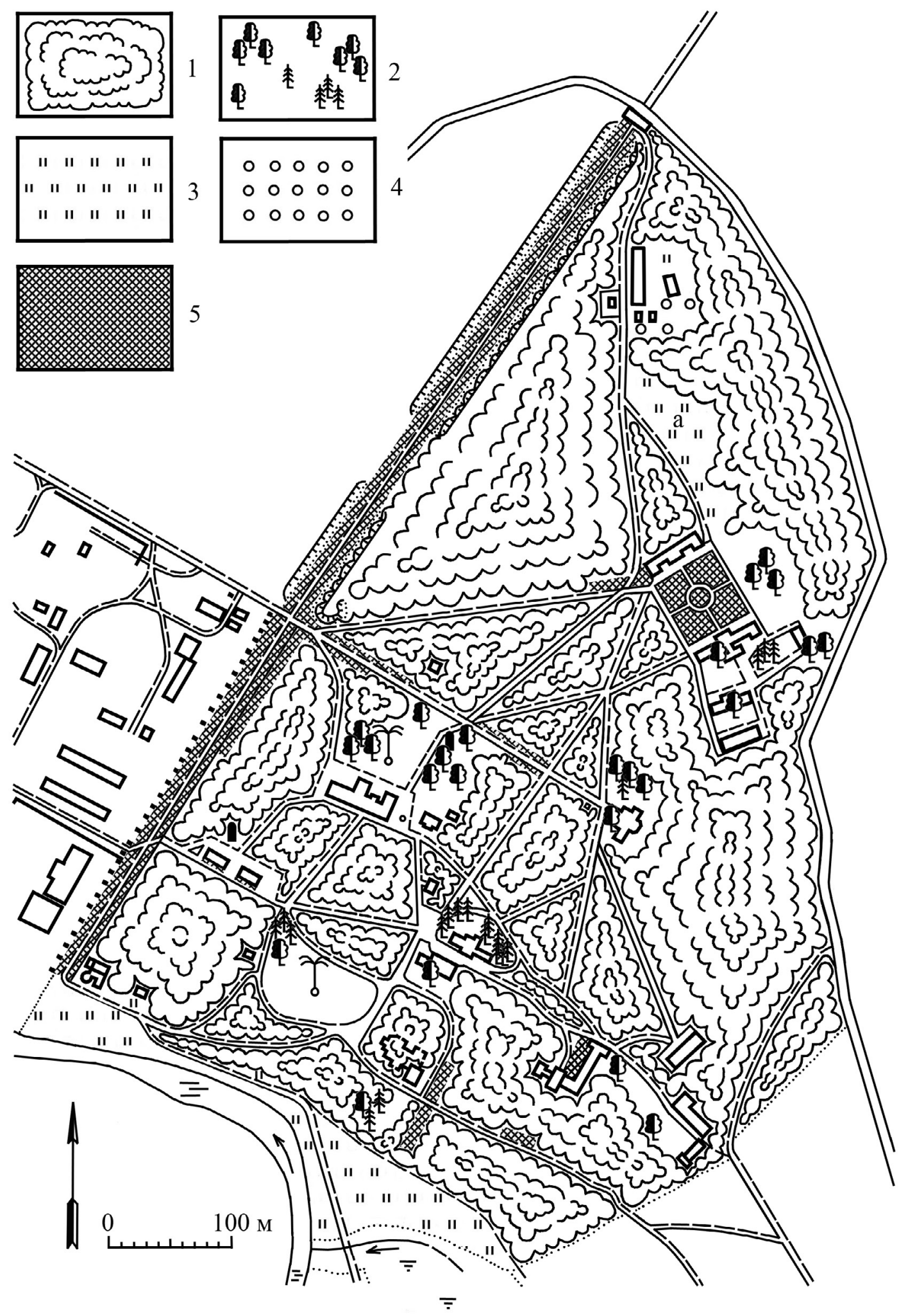

Figure 3. The schematic plan of landscapes at the Nataliivskyi Park in 1997: 1 - sylvatic; 2 - park; 3 - meadow; 4 - garden; 5 - regular and its elements. 


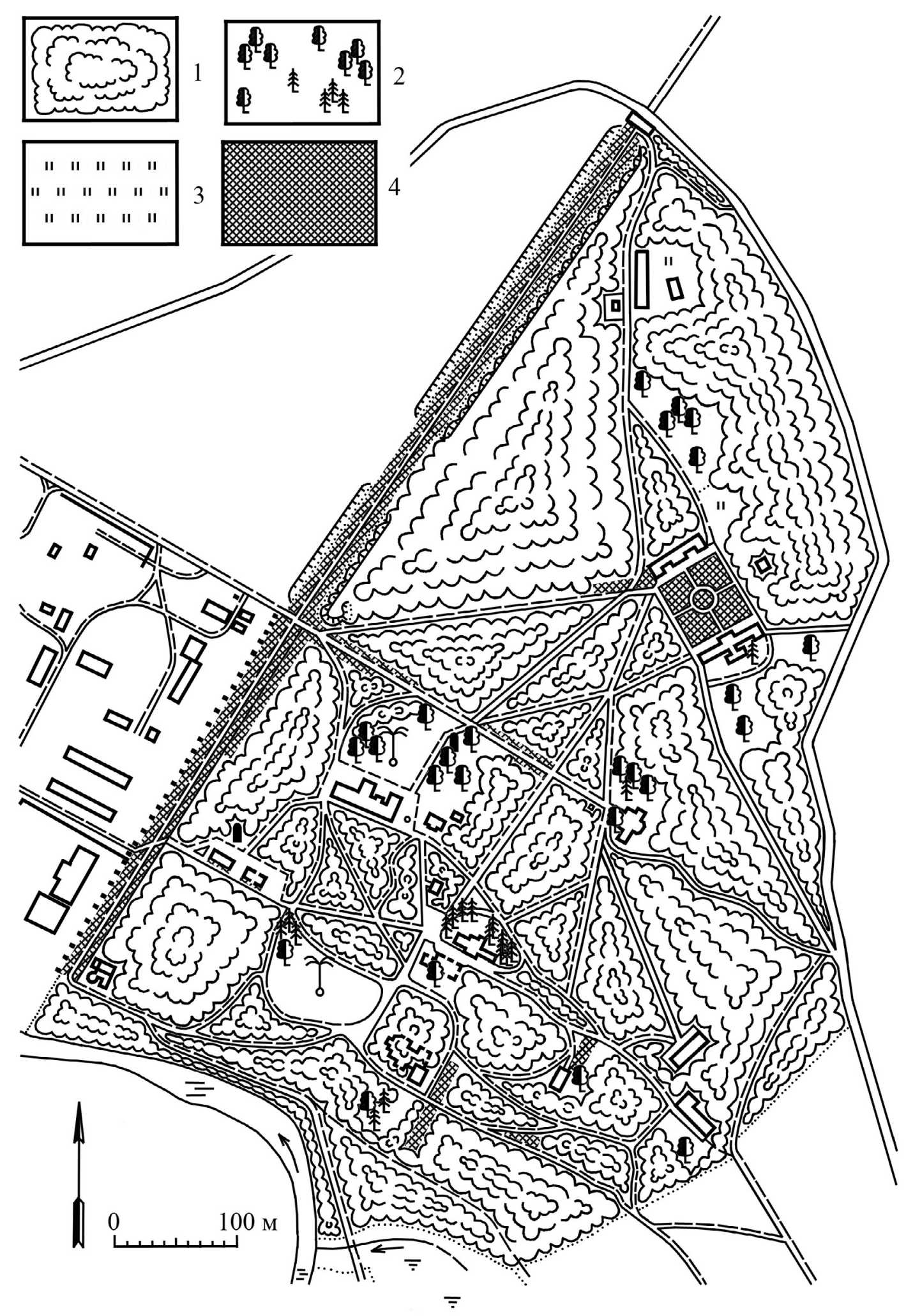

Figure 4. The schematic plan of landscapes at the Nataliivskyi Park in 2019:1 - sylvatic; 2 - park; 3 - meadow; 4 - regular and its elements. 
Table 2. The dynamics of the distribution of landscape types in the Nataliivskyi Park.

\begin{tabular}{lllll}
\hline \multirow{2}{*}{ Landscape type } & \multicolumn{3}{c}{1997} & \multicolumn{2}{c}{2019} \\
\cline { 2 - 5 } & Area, ha & Area, \% & Area, ha & Area, \% \\
\hline Sylvatic & 26.80 & 77.4 & 29.55 & 85.5 \\
Park & 2.80 & 8.1 & 2.60 & 7.5 \\
Regular & 2.30 & 6.6 & 2.30 & 6.7 \\
Meadow & 2.60 & 7.5 & 0.10 & 0.3 \\
Garden & 0.15 & 0.4 & 0.00 & 0.0 \\
\hline Total & 34.65 & 100.0 & 34.55 & 100.0 \\
\hline
\end{tabular}

were occupied by Acer negundo and almost completely disappeared. The garden landscape type has disappeared at all.

\section{Conclusions}

1. The taxonomic diversity of the dendroflora of the Nataliivskyi Park has increased by ten taxa since 1997. Although comparing with the heyday (early XX century), it lost many valuable representatives. Many taxa are currently represented in the park by few or single plants, and without regenerative plantings, these taxa can be lost.

2. Pine and oak plantings in the park stay in stable condition. Total areas of those plantings almost did not change.

3. Many areas the Nataliivskyi Park were occupied by self-seeding of Acer negundo and Robinia pseudoacacia, which led to the loss of meadow and garden landscapes. Sanitary felling combined with other special measures would help to restore primary landscapes.

4. The cover of sylvatic landscapes increased, while the area of other landscape types in most cases decreased.

\section{References}

Agaltsova, V. A. (1980). Preservation of memorial forest parks. Forest industry. (In Russian)

Bondar, Y. A., Salatich, A. K., \& Sadovenko Y. L. (1974). Restoration of old landscape parks. Vol. 1. Research Institute of Urban Development. (In Russian)

Ilinskaya, N. A. (1984). Reconstruction of historical objects of landscape architecture. Stroyizdat. (In Russian)
Klymenko, Y. O., \& Kuznetsov, S. I. (2015). General park sciences. Historical, biological and ecological, landscape and forestry approaches and methods. Comprint. (In Ukrainian)

Kokhno, M. A., Doroshenko, O. K., \& Chupryna, P. Y. (1975). Introduced trees and bushes of parks of the left-bank parts of Polissya and Forest-Steppe of Ukraine. Introduction and Acclimatization of Plants in Ukraine, 7, 27-41. (In Ukrainian)

Kurdyuk, M. G. (1966). Nataliivskyi Park in Kharkiv Region. In: Introduction and acclimatization of plants (pp. 151-153). Naukova Dumka. (In Ukrainian)

Lypa, O. L. (1960). Prominent gardens and parks of Ukraine and their protection. Kyiv University Press. (In Ukrainian)

Lypa, O. L., Kosarevskij, I. A., \& Salatich, A. L. (1952). Populated areas landscaping. AS UkrSSR. (In Russian)

Marchuk, O. O. (2006). Kharkiv region woody species biodiversity in arboretums and parks and their usage perspectives in forestry and landscaping [Dissertation thesis, G.N. Vysotsky Ukrainian Research Institute of Forestry and Agroforestry]. (In Ukrainian)

Mayak, A. S., \& Cherkasova, E. T. (1989). Kharkiv region garden and park arts monuments preservation problems. Building and Architecture, 9, 8-11. (In Russian)

Plants of the World Online (2021, 25 January). http://www.plantsoftheworldonline.org/

Rubtsov, L. I. (1956). Garden and park landscape. AS UkrSSR. (In Russian)

Rubtsov, L. I. (1979). Garden and park planning. Building Publisher. (In Russian)

Sikora, D. (2016). Zarys historii ochrony i konserwacji zabytków sztuki ogrodowej w Polsce. Ochrona Zabytków, 1, 105-142. http://cejsh.icm.edu.pl/ cejsh/element/bwmeta1.element.desklightabda10b2-854a-4b43-982e-c09d6f216276 
Uspenskaya, N. D., Klimenko, Y. A., Kuznetsov S. I., \& Davydenko, I. A. (1991). Formation of green spaces at the monuments of Ancient Rus. Naukova Dumka. (In Russian)
Zharikov, N. L. (Ed.). (1986). Ukrainian SSR monuments of urban planning and architecture. Vol. 4. Budivelnik. (In Russian)

\section{Дендрофлора Наталіївського парку (Харківська область, Україна): таксономічний склад та моніторинг насаджень}

Алла Григоренко ${ }^{1}$, Юрій Клименко ${ }^{2}$

1 Державна екологічна академія післядипломної освіти та управління, вул. Митрополита Василя Липківського, 35, Київ, 03035, Україна; alla_gr@ukr.net

2 Національний ботанічний сад імені М.М. Гришка НАН України, вул. Тімірязєвська, 1, Київ, 01014, Україна; klimenco109@ukr.net

3 метою розробки заходів з відновлення історичних насаджень та ландшафтів Наталіївського паркупам'ятки садово-паркового мистецтва (Харківська обл., Україна) у 2018-2019 рр. було здійснено моніторингові дослідження таксономічного складу дендрофлори, розподілу площі парку за видами, що переважають у виділах, і розподілу площі між типами садово-паркових ландшафтів за тією самою методикою, що була застосована Ю.О. Клименко у 1997 р. та з врахуванням опублікованих раніше даних.

У 1939 р. дендрофлора парку налічувала близько 100 таксонів. Згодом число таксонів значно зменшилось і в 1950 р. дендрофлора парку налічувала лише близько 40 таксонів. У 1997 році у Наталіївському парку було виявлено 74 таксони дерев і кущів. Наші нові дослідження показали, що від 1997 р. таксономічний склад дендрофлори парку збагатився на десять таксонів. Водночас відбулось зменшення участі цінних видів та культиварів у складі насаджень (окремі з них на сьогодні представлені лише однією-двома рослинами). Внаслідок нападу короїда-типографа на ослаблені посухами дерева Picea abies та P. pungens, більшість з них всохла. Площа виділів з домінуванням Pinus sylvestris та Quercus robur залишилась майже без змін, що свідчить про їхню загальну стійкість. Збільшилася площа виділів, де домінують натуралізовані інтродуценти Acer negundo і Robinia pseudoacacia та виділів, у яких жоден із видів не переважає. Відбувся перерозподіл площ на користь лісового типу садово-паркового ландшафту, а лучний тип ландшафту практично зник.

Для відновлення історичних насаджень та ландшафтів необхідно проводити висаджування рослин тих таксонів, які були представлені тут у період розквіту парку, та здійснювати рубки дерев інвазійних видів. Хоча наразі подібні рубки заборонені, дослідження свідчать, що вони можуть допомогти у збереженні таких заповідних об'єктів як Наталіївський парк. 